OPEN ACCESS

Edited by:

Boris Rewald,

University of Natural Resources and Life Sciences, Vienna, Austria

Reviewed by:

Jianquan Liu,

Lanzhou University/Sichuan University, China

Daniel R. Scholes,

University of Indianapolis, USA

*Correspondence:

Yuan-Wen Duan duanyw@mail.kib.ac.cn

Yong-Ping Yang yangyp@mail.kib.ac.cn

Specialty section:

This article was submitted to Functional Plant Ecology,

a section of the journal Frontiers in Plant Science

Received: 21 May 2016 Accepted: 18 August 2016 Published: 31 August 2016

Citation:

Guo W, Yang J, Sun X-D, Chen G-J, Yang Y-P and Duan Y-W (2016) Divergence in Eco-Physiological Responses to Drought Mirrors the Distinct Distribution of Chamerion angustifolium Cytotypes in the Himalaya-Hengduan Mountains

Region. Front. Plant Sci. 7:1329. doi: 10.3389/fp/s.2016.01329

\section{Divergence in Eco-Physiological Responses to Drought Mirrors the Distinct Distribution of Chamerion angustifolium Cytotypes in the Himalaya-Hengduan Mountains Region}

\author{
Wen Guo 1,2,3,4, Jie Yang ${ }^{5}$, Xu-Dong Sun 1,2,4, Guang-Jie Chen ${ }^{6}$, Yong-Ping Yang ${ }^{1,2,4 *}$ and \\ Yuan-Wen Duan ${ }^{1,2,4 *}$ \\ 1 Key Laboratory for Plant Diversity and Biogeography of East Asia, Kunming Institute of Botany, Chinese Academy of \\ Sciences, Kunming, China, ${ }^{2}$ Plant Germplasm and Genomics Center, Germplasm Bank of Wild Species, Kunming Institute \\ of Botany, Chinese Academy of Sciences, Kunming, China, ${ }^{3}$ University of the Chinese Academy of Sciences, Beijing, China, \\ ${ }^{4}$ Institute of Tibetan Plateau Research at Kunming, Kunming Institute of Botany, Chinese Academy of Sciences, Kunming, \\ China, ${ }^{5}$ School of Life Sciences, Yunnan Normal University, Kunming, China, ${ }^{6}$ Key Laboratory of Plateau Lake Ecology and \\ Global Change, School of Tourism and Geography, Yunnan Normal University, Kunming, China
}

Polyploid species generally occupy harsher habitats (characterized by cold, drought and/or high altitude) than diploids, but the converse was observed for Chamerion angustifolium, in which diploid plants generally inhabit higher altitudes than their polyploid derivatives. Plants at high altitudes may experience cold-induced water stress, and we therefore examined the physiological responses of diploid and hexaploid C. angustifolium to water stress to better understand the ecological differentiation of plants with different ploidy levels. We conducted a common garden experiment by subjecting seedlings of different ploidy levels to low, moderate, and severe water stress. Fourteen indicators of physiological fitness were measured, and the anatomical characteristics of the leaves of each cytotype were determined. Both cytotypes were influenced by drought, and diploids exhibited higher fitness in terms of constant root:shoot ratio (R:S ratio) and maximum quantum yield of PS II $\left(F_{\mathrm{v}} / F_{\mathrm{m}}\right)$, less reduced maximal photosynthetic rate $\left(A_{\max }\right)$, transpiration rate $(E)$, intercellular $\mathrm{CO}_{2}$ concentration $\left(C_{\mathrm{i}}\right)$ and stomatal conductance $\left(g_{\mathrm{s}}\right)$, and higher long-term water use efficiency (WUE $\left.\mathrm{L}\right)$ under severe water stress than did hexaploids. Analysis of leaf anatomy revealed morphological adjustments for tolerating water deficiency in diploids, in the form of closely packed mesophyll cells and small conduits in the midvein. Our results indicate that diploid C. angustifolium is more tolerant of drought than hexaploid plants, ensuring the successful survival of the diploid at high altitudes. This eco-physiological divergence may facilitate the species with different cytotypes to colonize new and large geographic ranges with heterogeneous environmental conditions.

Keywords: C. angustifolium, cytotype distribution, common garden experiment, drought tolerance, physiological fitness 


\section{INTRODUCTION}

Polyploidy, the state of having more than two complete chromosome sets per nucleus, has played a key role in the evolution and diversification of the plant kingdom (Leitch and Bennett, 1997; Soltis et al., 2009). Polyploidization can be accompanied by considerable cytological, morphological, and physiological alterations, meaning that ecological requirements can differ significantly between diploids and their polyploid derivatives (Ramsey and Schemske, 2002; Soltis et al., 2014). This may result in different adaptations in the different cytotypes and consequently in habitat segregation (Levin, 2004; te Beest et al., 2011), and it has long been hypothesized that polyploids may be able to occupy harsher environments relative to diploids because of the advantages of polyploidy (Grant, 1981; Levin, 1983). Observations supporting this hypothesis suggest that polyploids are common in alpine regions, arctic areas (Brochmann et al., 2004) and other ecologically extreme environments (Ramsey, 2011; Manzaneda et al., 2012; Hao et al., 2013; McAllister et al., 2015). However, many examples suggest that the frequency of diploids also tends to increase with altitude (Hardy et al., 2000; Sonnleitner et al., 2010) or latitude (Ricca et al., 2008), indicating that diploids may be more tolerant of certain stressful conditions (Buggs and Pannell, 2007; Visser and Molofsky, 2015). These conflicting results suggest that polyploids may not necessarily occupy more extreme habitats than their diploid parents, but rather can be regarded as 'fill-in' taxa that occupy habitats which become available for them.

Knowledge about the geographical distributions of different cytotypes may offer insights into the mechanisms responsible for their spatial separation (Duchoslav et al., 2010). In high-altitude mountains, the growth and reproduction of plants may be strongly influenced by low temperatures (Angert, 2006) and coldinduced drought stress (physiological drought; Hammel, 1967; Pockman and Sperry, 1996; Zhu et al., 2000). As a consequence, plants growing in high-altitude regions have developed various mechanisms to enhance their drought tolerance (Ma et al., 2010, 2014; Yang and Miao, 2010). Polyploids usually have larger xylem conduits than diploids due to chromosome doubling effects (Graciano-Ribeiro and Nassar, 2012; Hao et al., 2013); these conduits confer high levels of water transport efficiency (Maherali et al., 2009) but may be vulnerable to cavitation under drought stress due to the inverse relationship between hydraulic conductance and protection against embolism (Piñol and Sala, 2000; Martínez et al., 2002). On the contrary, narrow xylem conduits tend to have fewer and smaller pit membrane pores to reduce the occurrence of air seeding under high xylem tension (Wheeler et al., 2005), thus they might offer a selective advantage for diploids at high altitudes by minimizing the risk cost associated with xylem embolism.

As one of the most important biodiversity hotspots at similar latitudes in the Northern Hemisphere ( $\mathrm{Wu}$ and $\mathrm{Wu}, 1998)$, the Himalaya-Hengduan Mountains region (HHMs) contains over 20,000 species of vascular plants, and harbors very rich alpine flora with a profusion of endemic species (Wu, 1988; $\mathrm{Li}$ and $\mathrm{Li}$, 1993). Although it has been proposed that polyploidy has played only a minor role in plant diversification in this region (Liu,
2004; Nie et al., 2005; Yuan and Yang, 2008), the frequency of polyploidy is relatively high in some genera occurring there, for example, Buddleja (Chen G. et al., 2007), Rheum (Liu et al., 2010), Anaphalis (Meng et al., 2014), Meconopsis (Xie et al., 2014), and Ephedra (Wu et al., 2016). Recent cytogeographical investigations have indicated the importance of cytotype distribution patterns and have revealed altitudinal segregation between different ploidy levels in the HHMs region (Li et al., 2010; Yu et al., 2010; Zhai et al., 2011; Liang et al., 2015). However, the mechanisms underlying cytotype distribution still remain unclear, especially with respect to the roles played by physiological endurance in ecological differentiation among different cytotypes.

Chamerion angustifolium L. Holub (Onagraceae) is widespread throughout the northern hemisphere. This species is an autopolyploid perennial, with diploid $(2 n=36)$, tetraploid $(2 n=72)$, and hexaploid $(2 n=108)$ cytotypes (Mosquin, 1967; Chen J.R. et al., 2007). In the HHMs, the species generally occupies open and disturbed habitats, and it has been observed that diploid plants inhabit higher altitudes than polyploid plants, which is consistent with the patterns of distribution in north America (Mosquin, 1967; Husband and Schemske, 1998; Chen J.R. et al., 2007). Recent studies have suggested that the current distribution of diploid and tetraploid C. angustifolium across elevations may be the result of differences in physiological tolerances to drought or cold (Thompson et al., 2014) and the adaptation to native elevation of each cytotype (Martin and Husband, 2013). In the present study, we therefore aimed to quantitatively examine the responses of different cytotypes of C. angustifolium to drought stress, with an emphasis on testing the hypothesis that conduits might be narrower in diploid than in polyploid plants, a factor which could explain to a certain extent the vicarious distribution of this plant species along altitudinal gradients.

\section{MATERIALS AND METHODS}

\section{Collections of Material}

In 2013, we obtained all seeds used in the present study from two open-pollinated populations on Baima Snow Mountain, Yunnan province. The pure diploid population was located on a site at a higher altitude $\left(28^{\circ} 23^{\prime} 38^{\prime \prime} \mathrm{N}, 98^{\circ} 59^{\prime} 32^{\prime \prime} \mathrm{E}, 4160 \mathrm{~m}\right)$ than the pure hexaploid population $\left(28^{\circ} 25^{\prime} 38^{\prime \prime} \mathrm{N}, 98^{\circ} 58^{\prime} 15^{\prime \prime} \mathrm{E}, 3560 \mathrm{~m}\right)$. In each population, mature fruits and a small amount of leaf tissue were collected from multiple maternal plants. All seeds and leaf tissues were brought to the laboratory at Kunming Institute of Botany within $36 \mathrm{~h}$ and kept at $4^{\circ} \mathrm{C}$.

\section{Ploidy Determination}

We used flow cytometry and root-tip squashes to examine the ploidy of maternal plants. Approximately $1 \mathrm{~cm}^{2}$ fresh leaf tissue was chopped in $1.5 \mathrm{ml}$ of pre-chilled WPB buffer $(0.2 \mathrm{~mol} / \mathrm{L}$ Tris. $\mathrm{HCl}, 4 \mathrm{mmol} / \mathrm{L} \mathrm{MgCl} 2 \cdot 6 \mathrm{H}_{2} \mathrm{O}, 2 \mathrm{mmol} / \mathrm{L} \mathrm{EDTA} \mathrm{Na} 2 \cdot 2 \mathrm{H}_{2} \mathrm{O}$, $86 \mathrm{mmol} / \mathrm{L} \mathrm{NaCl}, 10 \mathrm{mmol} / \mathrm{L}$ sodium metabisulfite, $1 \%$ PVP$10,1 \%(\mathrm{v} / \mathrm{v})$ Triton $\mathrm{X}-100, \mathrm{pH}$ 7.5). Fresh leaves from an Oryza sativa $\mathrm{L}$. inbred line were chopped for use as an external standard $(\mathrm{C}$-value $=0.86 \mathrm{pg} / 2 \mathrm{C})$. After filtration, centrifugation, 
re-suspension and storage in the dark at $4^{\circ} \mathrm{C}$ for 10 min staining with $150 \mu \mathrm{l}$ propidium iodide, the resulting cell suspensions were analyzed using a FACS-Vantage flow cytometer following the manufacturer's recommendations (Partec, Germany; Tian et al., 2011). The histograms were analyzed with the FlowMax software package (Version 2.8.2, Partec GmbH, Germany). The FL2-area parameter (integrated fluorescence) was used to quantify DNA content. To examine the relationship between DNA content and ploidy, we carried out chromosome counts on root tips from seeds germinated in a Petri dish containing moist filter paper (Liu et al., 2006).

After identifying the ploidy of each maternal plant, seeds were germinated in plug trays filled with homogeneous humus soil, and placed in a canopied and naturally lit glasshouse at Yunnan Normal University. For each ploidy level, 180 robust seedlings of similar size were transplanted into pots (two seedlings per pot) 1 month later. All pots contained the same weight of a uniform mixture comprising equal volumes of peat and perlite. Soil surfaces were covered with a small quantity (c. $40 \mathrm{~g}$ ) of perlite to minimize evaporation. Pots were randomly positioned on a single glasshouse bench and watered every other day to maintain saturation for 2 months. At the rosette stage, leaf tissue was sampled from each plant and re-screened using flow cytometry to exclude any seedlings of other ploidy levels.

\section{Glasshouse Drought Experiments}

After 2 months of growth, we began drought stress treatments. Mortality following transplantation reduced the sample sizes for diploids and hexaploids to 78 and 80 pots, respectively. Fifteen 'empty' pots were filled with the same amount of the same soil mixture to measure soil evaporation rates. The remaining pots of seedlings and the 'empty' pots were divided into low, moderate, and severe water stress treatments. Water stress was applied by watering to 80,50 , and $20 \%$ of maximum field capacity (FC). Soil water content was maintained at these levels by weighing the pots every 2 days, recording the amount of water loss and rewatering to the required water levels immediately. The experimental period commenced on July 9, 2014 (day $\mathrm{t}_{1}$ ), and continued until August 10, 2014 (day $\mathrm{t}_{2}$ ). During this period, no fertilizer was added to any pot. The sides of the glasshouse were always open for aeration throughout the experiment, so that the temperature inside the glasshouse was closely linked to the ambient outside temperature (Yang et al., 2014).

\section{Growth and Water Use}

For growth and water use measurements, each pot was treated as a replicate, with its two seedlings being measured together. To estimate biomass increment during the experiment, 5 pots of each cytotype at the beginning of the experiment $\left(t_{1}\right)$ and 15 pots (five pots per treatment) at the end of the experiment $\left(t_{2}\right)$ were harvested. From each pot, the two seedlings were bulked together, and then divided into two parts: roots, and all aboveground parts including stems, leaves, and flowers. The total weight of each part was then determined after drying in an oven at $80^{\circ} \mathrm{C}$ for $48 \mathrm{~h}$. The dry mass ( $\mathrm{dm}$ ) accumulated during the experimental period in the root [root dry mass (RDM)] and the aboveground parts dry mass $(\mathrm{ADM})$ was calculated by subtracting $\mathrm{dm}$ per pot at day $t_{1}$ from that at day $t_{2}$, for each cytotype and treatment type, and dividing by two to convert from per pot to per plant. Total dry mass (TDM) was the sum of RDM and ADM, and the ratio of root to shoot (R:S ratio) was calculated by dividing RDM by ADM.

From both empty pots and those containing seedlings, water loss was measured as the difference between the weight of each pot just after watering and that just before the next watering event, $48 \mathrm{~h}$ later. These measurements were taken throughout the experimental period. Within each watering treatment, the amount of water transpired per pot per day for each cytotype was determined by deducting mean daily water loss per empty pot (evaporation) from mean daily water loss per pot with plants (evaporation plus transpiration). From this, total transpired water use (TWU) per plant was calculated as the total water transpired per pot between day $\mathrm{t}_{1}$ and day $\mathrm{t}_{2}$ divided by two.

Long-term water use efficiency (WUE $\mathrm{L}_{\mathrm{L}}$ ) per plant, defined as the ratio between biomass production and water consumption for transpiration, was calculated, for each cytotype and treatment, as TDM/TWU (Ma et al., 2010).

\section{Gas Exchange, Transpiration, and Chlorophyll Fluorescence}

Five to six pots for each treatment per ploidy level were randomly selected to measure gas exchange characteristics. For each pot, the fifth leaf down from the top, which was fully opened and matured, was selected on one plant, and the maximum photosynthetic rate $\left(A_{\max }\right)$, stomatal conductance $\left(g_{\mathrm{s}}\right)$, intercellular $\mathrm{CO}_{2}$ concentration $\left(C_{\mathrm{i}}\right)$ and transpiration rate $(E)$ were measured simultaneously using a LI-6400 XT infrared gas-analyser (LICor Inc., Lincoln, NE, USA) for that plant. Measurements were taken between 9:30 and 12:00 h during sunny weather. Light levels were maintained at $1600 \mu \mathrm{mol} \mathrm{m} \mathrm{m}^{-2} \mathrm{~s}^{-1}$ (light-saturation points were derived from light response curves determined before the experiment) using artificial light provided by an LI-640002B LED light source (LI-COR Biosciences). The external $\mathrm{CO}_{2}$ concentration was maintained at $400 \mu \mathrm{mol} \mathrm{mol}^{-1}$ using portable $\mathrm{CO}_{2}$ /air mixture tanks whose output was controlled by a LI-6400$01 \mathrm{CO}_{2}$ injector (LI-COR Biosciences). Temperature and relative humidity were maintained at $24-26^{\circ} \mathrm{C}$ and $23-29 \%$, respectively. Due to the lanceolate leaves of $C$. angustifolium usually couldn't cover the leaf chamber $\left(6 \mathrm{~cm}^{2}\right)$, leaves were cut and scanned using a Canon Scan Lide 110 after the measurements had been taken. Then the leaf areas were analyzed by Scion Image (Version 4.0.3, National Institutes of Health, USA) so that leaf gas exchange parameters could be calculated on a per area basis. Instantaneous water use efficiency $\left(\mathrm{WUE}_{\mathrm{i}}\right)$ was defined and calculated as $A_{\max } / E$ (Sapeta et al., 2013).

Chlorophyll fluorescence parameters were measured between 6:00 and 7:00 $\mathrm{h}$ on leaves that had been dark adapted for $10 \mathrm{~h}$. These measurements were taken on the same day as the leaf gas exchange measurements. The maximum quantum yield of photosystem II [PSII; $F_{\mathrm{v}} / F_{\mathrm{m}}=\left(F_{\mathrm{m}}-F_{\mathrm{o}}\right) / F_{\mathrm{m}}$ ] was measured using a LI-6400-40 leaf chamber fluorometer (LI-COR Biosciences). Five plants in each treatment per cytotype were analyzed (Mena-Petite et al., 2000). 


\section{Leaf Water Status}

To determine leaf water status, leaves were collected from other five different plants in one treatment. One fully mature leaf of each selected plant was stored in plastic bag on wet tissues until required for measurement of leaf area. The method used for analyzing leaf area was as described in the gas exchange section. The fresh mass (fm) of the measured leaves was then determined. Before measuring the saturated mass $(\mathrm{sm})$ of the leaves, we allowed them to become turgid by resting them in water for $1 \mathrm{~h}$. Leaves were oven-dried at $80^{\circ} \mathrm{C}$ for 48 hours before $\mathrm{dm}$ was determined. Relative water content (RWC) was expressed as $100 \%[(\mathrm{fm}-\mathrm{dm}) /(\mathrm{sm}-\mathrm{dm})]$ (Yamasaki and Dillenburg, 1999). Leaf dry mass per unit area (LMA) was also calculated.

\section{Leaf Anatomy}

Leaves harvested from each of five different plants in one treatment were preserved in malondialdehyde (MDA). The $5 \mathrm{~mm} \times 5 \mathrm{~mm}$ fragments from the adaxial side of the leaf and the midrib were used for embedding. The sample was incubated successively in the following solutions: $0.1 \mathrm{M}$ PBS for $10 \mathrm{~min}$ (three times), 30\% ethanol for $1 \mathrm{~h}, 50 \%$ ethanol for $1 \mathrm{~h}, 70 \%$ ethanol for $1 \mathrm{~h}, 80 \%$ ethanol for $1 \mathrm{~h}, 90 \%$ ethanol for $1 \mathrm{~h}, 95 \%$ ethanol for $1 \mathrm{~h}, 100 \%$ ethanol for $1 \mathrm{~h}, 100 \%$ ethanol:histoclear (1:1) for $4 \mathrm{~h}$, histoclear for $1 \mathrm{~h}$ (two times), histoclear:paraffin (1:1) for $12 \mathrm{~h}\left(40^{\circ} \mathrm{C}\right)$, histoclear:paraffin $(1: 1)$ for $4 \mathrm{~h}\left(60^{\circ} \mathrm{C}\right)$, paraffin for $4 \mathrm{~h}\left(60^{\circ} \mathrm{C}\right)$, and paraffin for $12 \mathrm{~h}\left(60^{\circ} \mathrm{C}\right)$, and leaf tissues were then embedded in paraffin. Transverse cross-sections of the embedded samples were obtained with a microtome (Leica RM 2015) equipped with a freshly produced glass knife (Leica 819). The sections were then placed on glass slides.

For histochemical analyses, $12-\mu \mathrm{m}$-thick sections were stained with $1 \%$ Safranin for $12 \mathrm{~h}$ and $1 \%$ Fast Green for $10 \mathrm{~s}$. In order to examine the lignified cell walls in midribs, $50-\mu \mathrm{m}$-thick sections were stained for $5 \mathrm{~min}$ with $1 \%$ phloroglucinol in $6 \mathrm{~N} \mathrm{HCl}$ (Zhou et al., 2009). Stained cross sections were scanned using a brightfield microscopy (Leica DM 1000; Sun et al., 2013).

Leaf blade thickness, palisade parenchyma thickness, lacunar parenchyma thickness, leaf central vein diameter, xylem conduit diameter, leaf central vein total area, and xylem cell area were then measured from digital photographs with the Image J software (Version 1.45, National Institutes of Health, USA).

\section{Statistical Analyses}

Data for all measured variables were analyzed using the general linear model (PROC GLM) to test the effects of cytotype, treatments, and their interactions. Significant differences among treatments for each cytotype were compared using one-way analysis of variance (ANOVA), and an independent-samples $t$ test was used to compare the differences among cytotypes for each treatment. The homogeneity of variances was tested before analysis. Separate one-way ANOVAs were performed which assume independence between dependent variables and multiple traits measured for individual plants, but due to insufficient statistical power, correction of family-wise error rates for trait functional groups or individuals could not be performed. All statistical analyses were carried out using the SPSS statistical software package (Version 19.0, IBM, USA).

\section{RESULTS}

\section{Cytotype Composition}

Flow cytometry analyses revealed two DNA ploidy levels in our samples: DNA-diploid (1.081 $\pm 0.009 \mathrm{pg} / 2 \mathrm{C})$ and DNAhexaploid (3.008 $\pm 0.084 \mathrm{pg} / 2 \mathrm{C})$. The hexaploids thus had triple the DNA content of the diploids, a finding which was confirmed by chromosome counts.

\section{Plant Growth and Water Use Traits}

Diploids and hexaploids of C. angustifolium exhibited different biomass allocation strategies in response to drought stress, and diploids generally accumulated more biomass during the experiment across all water gradients than hexaploids. The differences between cytotypes were significant for TDM accumulation and ADM accumulation under high water stress, and for RDM accumulation under low water stress (Table 1). Although TDM apparently declined in both cytotypes as the available soil water decreased, both ADM and RDM decreased in diploids, whereas hexaploids only showed a reduction in ADM. Due to the difference in dry weight allocation, water stress did not result in a significant difference for the R:S ratio in diploids, but it caused a significant increase in hexaploids (Figure 1).

Total TWU decreased significantly with decreasing soil water content in both cytotypes (Table 1). From low to severe water stress, diploids experienced a significant increase in $\mathrm{WUE}_{\mathrm{L}}$ but hexaploids did not. Furthermore, diploids had higher WUE $\mathrm{L}_{\mathrm{L}}$ than hexaploids under severe water stress (Table 1). Transpiration rate $(E)$ and $W_{U} E_{i}$ differed significantly among the three soil water contents (Tables 1 and 2). E decreased significantly with increasing water stress in both cytotypes, leading to a significant increase in $\mathrm{WUE}_{\mathrm{i}}$ (Figure 2). Of the two ploidy levels, diploids had significantly lower $E$ and higher $W_{U} E_{i}$ than hexaploids under low water stress.

\section{Leaf Photosynthesis and Chlorophyll Fluorescence}

Maximal photosynthetic rate $\left(A_{\max }\right)$, intercellular $\mathrm{CO}_{2}$ concentration $\left(C_{\mathrm{i}}\right)$ and stomatal conductance $\left(g_{\mathrm{s}}\right)$ decreased significantly as water stress increased (Table 1), and there were significant differences between cytotypes in these three variables under specific drought stress treatments (Tables 1 and 2). Diploids had a higher value of $A_{\max }$ than hexaploids in all drought stress treatments and the difference was significant under 20\% maximum FC (Table 1). The values of $C_{\mathrm{i}}$ and $g_{\mathrm{s}}$ were significantly higher in hexaploids than in diploids under low stress, whereas these differences were reduced and no significant difference could be detected under medium or high water stress (Table 1).

Maximum quantum yield of PS II $\left(F_{\mathrm{v}} / F_{\mathrm{m}}\right)$ was similar between cytotypes for $80 \%$ FC and $50 \%$ FC, but it was significantly lower in hexaploids than in diploids under severe drought stress treatment (Table 1). 
TABLE 1 | Comparison of 11 measured indicators between Chamerion angustifolium diploids and hexaploids, across three different soil water treatments ( $80 \%$ of maximal field capacity (FC), $50 \%$ FC, and $20 \%$ FC).

\begin{tabular}{|c|c|c|c|}
\hline \multirow[b]{3}{*}{ Variable and cytotype } & \multicolumn{3}{|c|}{ Water treatment (\% of maximum FC) } \\
\hline & Low stress & Medium stress & High stress \\
\hline & $80 \%$ FC & $50 \%$ FC & $20 \%$ FC \\
\hline \multicolumn{4}{|l|}{ Total dry mass (TDM) (g) } \\
\hline Diploid & $2.016 \pm 0.452 \mathrm{~A}, \mathrm{X}$ & $0.956 \pm 0.082 \mathrm{~B}, \mathrm{X}$ & $0.558 \pm 0.087 \mathrm{~B}, \mathrm{X}$ \\
\hline Hexaploid & $1.086 \pm 0.152 \mathrm{~A}, \mathrm{Y}$ & $0.784 \pm 0.128 \mathrm{~A}, \mathrm{X}$ & $0.233 \pm 0.061 \mathrm{~B}, \mathrm{Y}$ \\
\hline \multicolumn{4}{|c|}{ Aboveground parts dry mass (ADM) (g) } \\
\hline Diploid & $1.877 \pm 0.428 \mathrm{~A}, \mathrm{X}$ & $0.866 \pm 0.079 \mathrm{~B}, \mathrm{X}$ & $0.503 \pm 0.076 \mathrm{~B}, \mathrm{X}$ \\
\hline Hexaploid & $1.041 \pm 0.150 \mathrm{~A}, \mathrm{Y}$ & $0.739 \pm 0.118 \mathrm{~A}, \mathrm{X}$ & $0.170 \pm 0.071 \mathrm{~B}, \mathrm{Y}$ \\
\hline \multicolumn{4}{|c|}{ Root dry mass (RDM) (g) } \\
\hline Diploid & $0.139 \pm 0.025 \mathrm{~A}, \mathrm{X}$ & $0.091 \pm 0.016 \mathrm{~A}, \mathrm{~B}, \mathrm{X}$ & $0.055 \pm 0.012 \mathrm{~B}, \mathrm{X}$ \\
\hline Hexaploid & $0.045 \pm 0.006 \mathrm{~A}, \mathrm{Y}$ & $0.046 \pm 0.016 \mathrm{~A}, \mathrm{Y}$ & $0.051 \pm 0.013 \mathrm{~A}, \mathrm{X}$ \\
\hline \multicolumn{4}{|c|}{ Maximal photosynthetic rate $\left(A_{\max }\right)\left(\mu \mathrm{mol} \mathrm{CO} \mathrm{m}^{-2} \mathrm{~s}^{-1}\right)$} \\
\hline Diploid & $12.879 \pm 0.528 \mathrm{~A}, \mathrm{X}$ & $10.407 \pm 0.429 \mathrm{~B}, \mathrm{X}$ & $7.818 \pm 0.752 \mathrm{C}, \mathrm{X}$ \\
\hline Hexaploid & $11.958 \pm 0.495 \mathrm{~A}, \mathrm{X}$ & $9.828 \pm 0.641 \mathrm{~B}, \mathrm{X}$ & $5.508 \pm 0.318 \mathrm{C}, \mathrm{Y}$ \\
\hline \multicolumn{4}{|c|}{ Transpiration rate $(E)\left(\mathrm{mmol} \mathrm{H}_{2} \mathrm{O} \mathrm{m}^{-2} \mathrm{~s}^{-1}\right)$} \\
\hline Diploid & $6.261 \pm 0.314 \mathrm{~A}, \mathrm{X}$ & $7.043 \pm 0.455 \mathrm{~A}, \mathrm{X}$ & $2.751 \pm 0.192 \mathrm{~B}, \mathrm{X}$ \\
\hline Hexaploid & $9.488 \pm 0.189 \mathrm{~A}, \mathrm{Y}$ & $8.174 \pm 0.460 \mathrm{~B}, \mathrm{X}$ & $2.385 \pm 0.378 \mathrm{C}, \mathrm{X}$ \\
\hline \multicolumn{4}{|c|}{ Intercellular $\mathrm{CO}_{2}$ concentration $\left(C_{\mathrm{i}}\right)\left(\mu \mathrm{mol} \mathrm{CO} \mathrm{Col}^{-1}\right)$} \\
\hline Diploid & $270.532 \pm 7.727 \mathrm{~A}, \mathrm{X}$ & $294.814 \pm 6.146 \mathrm{~B}, \mathrm{X}$ & $227.562 \pm 6.860 \mathrm{C}, \mathrm{X}$ \\
\hline Hexaploid & $312.072 \pm 2.703 \mathrm{~A}, \mathrm{Y}$ & $309.799 \pm 4.578 \mathrm{~A}, \mathrm{X}$ & $233.299 \pm 8.754 \mathrm{~B}, \mathrm{X}$ \\
\hline \multicolumn{4}{|c|}{ Stomatal conductance $\left(g_{\mathrm{s}}\right)\left(\mathrm{mmol} \mathrm{H} \mathrm{H}_{2} \mathrm{~m}^{-2} \mathrm{~s}^{-1}\right)$} \\
\hline Diploid & $0.231 \pm 0.016 \mathrm{~A}, \mathrm{X}$ & $0.223 \pm 0.020 \mathrm{~A}, \mathrm{X}$ & $0.078 \pm 0.005 B, X$ \\
\hline Hexaploid & $0.392 \pm 0.010 \mathrm{~A}, \mathrm{Y}$ & $0.286 \pm 0.026 \mathrm{~B}, \mathrm{X}$ & $0.058 \pm 0.010 \mathrm{C}, \mathrm{X}$ \\
\hline \multicolumn{4}{|c|}{ Maximum quantum yield of PS II $\left(F_{\mathrm{v}} / F_{\mathrm{m}}\right)$} \\
\hline Diploid & $0.816 \pm 0.003 \mathrm{~A}, \mathrm{X}$ & $0.808 \pm 0.005 \mathrm{~A}, \mathrm{X}$ & $0.808 \pm 0.005 \mathrm{~A}, \mathrm{X}$ \\
\hline Hexaploid & $0.812 \pm 0.002 \mathrm{~A}, \mathrm{X}$ & $0.806 \pm 0.004 \mathrm{~A}, \mathrm{X}$ & $0.770 \pm 0.006 \mathrm{~B}, \mathrm{Y}$ \\
\hline \multicolumn{4}{|c|}{ Total transpired water use (TWU) (kg) } \\
\hline Diploid & $0.689 \pm 0.169 \mathrm{~A}, \mathrm{X}$ & $0.358 \pm 0.039 \mathrm{~B}, \mathrm{X}$ & $0.136 \pm 0.021 \mathrm{~B}, \mathrm{X}$ \\
\hline Hexaploid & $0.456 \pm 0.049 \mathrm{~A}, \mathrm{X}$ & $0.309 \pm 0.029 \mathrm{~A}, \mathrm{X}$ & $0.074 \pm 0.007 \mathrm{~B}, \mathrm{Y}$ \\
\hline \multicolumn{4}{|c|}{ Long-term water use efficiency $\left(\mathrm{WUE}_{\mathrm{L}}\right)$} \\
\hline Diploid & $2.887 \pm 0.357 \mathrm{~A}, \mathrm{~B}, \mathrm{X}$ & $2.658 \pm 0.090 \mathrm{~A}, \mathrm{X}$ & $4.193 \pm 0.325 \mathrm{~B}, \mathrm{X}$ \\
\hline Hexaploid & $2.316 \pm 0.114 \mathrm{~A}, \mathrm{X}$ & $2.354 \pm 0.229$ A,X & $3.149 \pm 0.248 \mathrm{~A}, \mathrm{Y}$ \\
\hline \multicolumn{4}{|c|}{ Leaf relative water content (RWC) } \\
\hline Diploid & $0.898 \pm 0.014 \mathrm{~A}, \mathrm{X}$ & $0.869 \pm 0.005 \mathrm{~A}, \mathrm{X}$ & $0.790 \pm 0.010 \mathrm{~B}, \mathrm{X}$ \\
\hline Hexaploid & $0.873 \pm 0.013 \mathrm{~A}, \mathrm{X}$ & $0.861 \pm 0.009 \mathrm{~A}, \mathrm{X}$ & $0.843 \pm 0.018 \mathrm{~A}, \mathrm{Y}$ \\
\hline
\end{tabular}

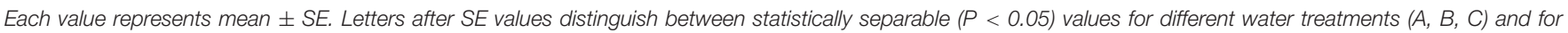
different cytotypes $(X, Y)$.

\section{Leaf Water Status and Histology}

A significant decrease in leaf RWC was observed with increasing water stress for diploids, but there was no significant difference for hexaploids (Table 1). The value of RWC was significantly lower in diploids than in hexaploids under 20\% FC. Leaf mass per unit area (LMA) varied significantly among water stress treatments and between ploidy levels. Drought stress gave rise to the increase in LMA from 50\% FC to $20 \%$ FC for both cytotypes, but diploids showed significantly higher LMA than hexaploids under $80 \%$ FC and $20 \%$ FC (Figure 3).

Cross sections of leaves indicated that the leaf blade was significantly thicker in diploid than in hexaploid plants because of the thicker palisade parenchyma under extreme water stress (Table 3; Figure 4). It is also worth noting that diploids always had a higher percentage of palisade parenchyma than hexaploids (Table 3; Figure 4). Consistent with the higher LMA observed for diploids under all soil water conditions and the compact cell packaging expected in leaves with higher LMA values, the palisade parenchyma cells in diploids were closely arranged, but those in hexaploids were more sparse (Figure 4). Hexaploids had significantly wider xylem conduits for low and medium stress and the xylem cell area in the leaf central vein was larger for diploids than that for hexaploids under severe water stress (Table 3; Figure 5). 


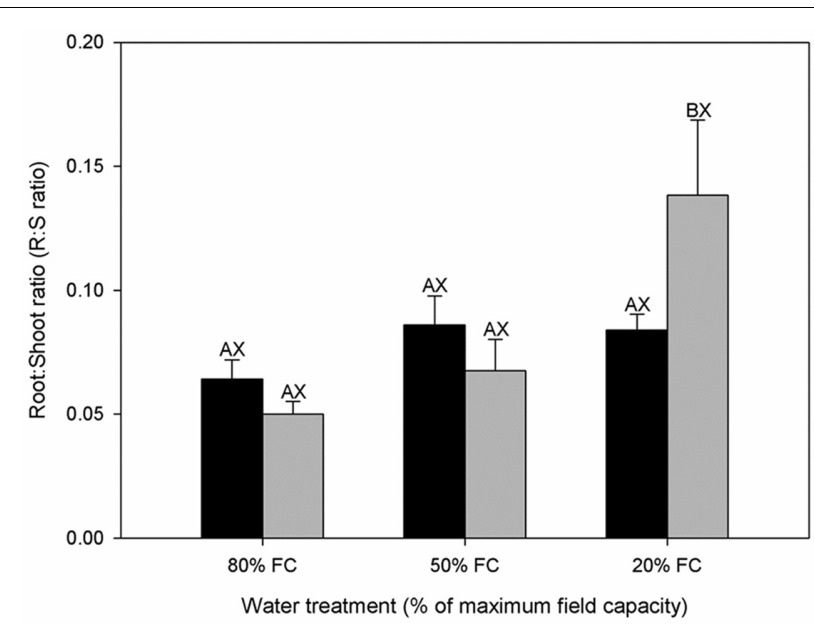

FIGURE 1 | Root:Shoot ratio (R:S ratio) of diploids (black bars) and hexaploids (gray bars) under different soil water conditions $(80 \%$ of maximal field capacity (FC), $\mathbf{5 0} \%$ FC, $\mathbf{2 0} \% \mathbf{F C )}$. Each value is presented as mean \pm SE. Letters distinguish between statistically separable $(p<0.05)$ values for different water treatments $(A, B, C)$ and for different cytotypes $(X, Y)$.

\section{DISCUSSION}

In the Himalaya-Hengduan Mountains region, limited biogeographic studies manifested that diploid and derivative polyploids colonizing different distribution areas (Liang et al., 2015; Wu et al., 2016), with some polyploids tending to occur at high altitudes, such as Aconitum (Yuan and Yang, 2006), Allium przewalskianum (Cui et al., 2008), and Anaphalis nepalensis (Meng et al., 2014). Although geographical segregation of cytotypes has long been recognized, the underlying mechanisms creating these patterns remain poorly understood (McIntyre, 2012). Ecological sorting along environmental gradients and adaptive differences among ploidy levels may trigger habitat divergence (Duchoslav et al., 2010), a possibility which can be examined quantitatively by means of common garden and/or transplant experiments (McIntyre, 2012; Godsoe et al., 2013; Theodoridis et al., 2013; Glennon et al., 2014; McAllister et al., 2015). In our field investigations, we found that diploids occupied habitats at higher altitudes than hexaploids, supporting the previously reported pattern of distribution of different C. angustifolium cytotypes (Husband and Schemske, 1998). By performing a common garden experiment with different water stresses, we evaluated variations in drought tolerance traits in diploid and polyploid plants, and our results suggested that divergence in drought tolerance between polyploids and their diploid ancestors may have promoted habitat differentiation and the spatial separation of cytotypes.

\section{EcoPhysiological Differentiation between Ploidy Levels}

Water availability as a growth limiting factor was demonstrated in the present study, since it caused significant reductions in TDM, RDM, and ADM, but the decreases in TDM and ADM in hexaploids were larger than those in diploids (Table 1). In addition, drought effects were more pronounced for above- than below-ground biomass in hexaploids, leading to an increase in R:S ratio, as would be generally expected (Fernandez and Reynolds, 2000; Otieno et al., 2005). Curiously, there was no detectable change in R:S ratio for diploid cytotype (Figure 1), indicating the existence of an intrinsic trait for coping with drought stress in diploid C. angustifolium (Ma et al., 2010; Ma et al., 2014). Plant growth is generally inhibited by water deficit before photosynthesis and maintenance of respiration, leading to the increase of non-structural carbon concentrations in tissues (Muller et al., 2011), which is commonly interpreted as osmotic adjustment (Hasibeder et al., 2015). During desiccation, parallel degree of osmotic adjustments-related assimilates allocation in roots and leaves may lead to the stable R:S ratio for perennial grasses to maintain water balance between organs, such as Helianthus annuus (Sobrado and Turner, 1986). This could explain the constant R:S ratio of diploids C. angustifolium across different gradients of water stress.

Drought can affect plant growth by influencing leaf gas exchange rates (Sapeta et al., 2013). Early responses to water deficit involve stomatal closure and a subsequent reduction in stomatal conductance (Chaves et al., 2002). The resulting reduction in leaf diffusive capacity then causes a simultaneous decline in $\mathrm{CO}_{2}$ uptake and transpiration during desiccation (Cornic and Massacci, 1996; Tezara et al., 1999). The magnitudes by which $g_{\text {s }}$ was reduced $(85.20 \%$ vs. $66.23 \%), C_{\mathrm{i}}(25.24 \%$ vs. $15.88 \%)$, and $E(74.86 \%$ vs. $56.06 \%)$ were greater in the hexaploids than in the diploids (Table 1). Lower $C_{\mathrm{i}}$ mediated by a reduction in leaf conductance may thus be inhibiting carbon metabolism in the face of drought stress (Downton et al., 1988; Maroco et al., 2002; Flexas et al., 2004) in both cytotypes (Table 1). Comparatively, diploids had a significantly higher $A_{\max }$ than hexaploids under severe water stress, and the reduction in $A_{\max }$ caused by drought in diploids (39.30\%) was lower than that in hexaploids (53.94\%; Table 1). Similarly, a higher photosynthetic rate during desiccation was found in diploids of Mercurialis annua (Buggs and Pannell, 2007) due to the case that polyploidy cytotype had lower transpiration rates and $\mathrm{CO}_{2}$ exchange rates under drought stress. Taking these results together, the fact that gas exchange was less depressed in diploids than in hexaploids would suggest that the former is better able to resist drought. Another reliable diagnostic indicator of plant photosynthetic activity is $F_{\mathrm{v}} / F_{\mathrm{m}}$ and its value often experiences a reduction under environmental stress (Maxwell and Johnson, 2000). Our results revealed that $F_{\mathrm{v}} / F_{\mathrm{m}}$ was significantly decreased by drought stress in hexaploids, to below the optimal value of 0.8 (Table 1) (MenaPetite et al., 2000), indicating the sensitivity of hexaploids to drought stress.

$\mathrm{WUE}_{\mathrm{i}}$ and $\mathrm{WUE}_{\mathrm{L}}$ were enhanced from $50 \% \mathrm{FC}$ to $80 \% \mathrm{FC}$ by increasing drought stress for both cytotypes (Table 1; Figure 2); similar results have been reported in other species (Zhang and Marshall, 1994). Plants with high water use efficiency should have greater abilities to survive drought stress than those with lower water use efficiency (Lauteri et al., 1997). Our results indicated that WUE in diploids increased relative to that in hexaploids under severe water stress, reflecting a water use 
TABLE 2 | Comparisons of all variables measured in this experiment for diploid and hexaploid C. angustifolium seedlings.

\begin{tabular}{|c|c|c|c|c|c|c|c|}
\hline Variable & Abb. & df & $\begin{array}{c}\text { Watering } \\
\text { treatment }\end{array}$ & df & Cytotypes & df & $\begin{array}{c}\text { Treatment * } \\
\text { cytotypes } \\
\text { interaction }\end{array}$ \\
\hline Total dry mass & TDM & 2 & $13.753^{* * *}$ & 1 & $7.014^{*}$ & 2 & 1.731 \\
\hline Aboveground parts dry mass & ADM & 2 & $14.367 * * *$ & 1 & $6.414^{*}$ & 2 & 1.602 \\
\hline Root dry mass & RDM & 2 & 3.143 & 1 & $13.702^{* *}$ & 2 & $4.143^{*}$ \\
\hline Root:Shoot ratio & $\mathrm{R}: \mathrm{S}$ ratio & 2 & $6.713^{*}$ & 1 & 0.358 & 2 & $3.752 *$ \\
\hline Maximal photosynthetic rate & $A_{\max }$ & 2 & $56.42^{* * *}$ & 1 & $8.134^{* *}$ & 2 & 1.413 \\
\hline Transpiration rate & $E$ & 2 & $146.417^{* * *}$ & 1 & $21.749 * * *$ & 2 & $13.339^{* * *}$ \\
\hline Intercellular $\mathrm{CO}_{2}$ concentration & $C_{i}$ & 2 & $72.102^{* * *}$ & 1 & $15.541^{* *}$ & 2 & $4.154^{*}$ \\
\hline Stomatal conductance & $g_{\mathrm{s}}$ & 2 & $124.880^{* * *}$ & 1 & $26.736^{* * *}$ & 2 & $15.760^{* * *}$ \\
\hline Maximum quantum yield of PS II & $F_{\mathrm{v}} / F_{\mathrm{m}}$ & 2 & $20.554^{* * *}$ & 1 & $20.126^{* * *}$ & 2 & $12.763^{* * *}$ \\
\hline Instantaneous water use efficiency & WUE $_{i}$ & 2 & $51.247^{* * *}$ & 1 & $25.894^{* * *}$ & 2 & 2.535 \\
\hline Total transpired water use & TWU & 2 & $4.064^{*}$ & 1 & 2.762 & 2 & 0.344 \\
\hline Long-term water use efficiency & WUE $E_{L}$ & 2 & $16.818^{* * *}$ & 1 & $5.877^{*}$ & 2 & 1.538 \\
\hline Leaf relative water content & RWC & 2 & $6.186^{* *}$ & 1 & 0.594 & 2 & 2.792 \\
\hline Leaf mass per unit area & LMA & 2 & $6.690^{* *}$ & 1 & $12.862^{* *}$ & 2 & 0.269 \\
\hline
\end{tabular}

$P$-values are presented for watering treatment, cytotype, and their interaction.

$* P<0.05 ; * * P<0.01 ; * * * P<0.001$.

TABLE 3 | Anatomical characteristics of leaf blade and leaf central vein from diploid and hexaploid C. angustifolium under three different soil water treatments ( $80 \%$ of maximal FC, $50 \%$ FC, and $20 \% \mathrm{FC}$ ).

Water treatment (\% of maximum FC)

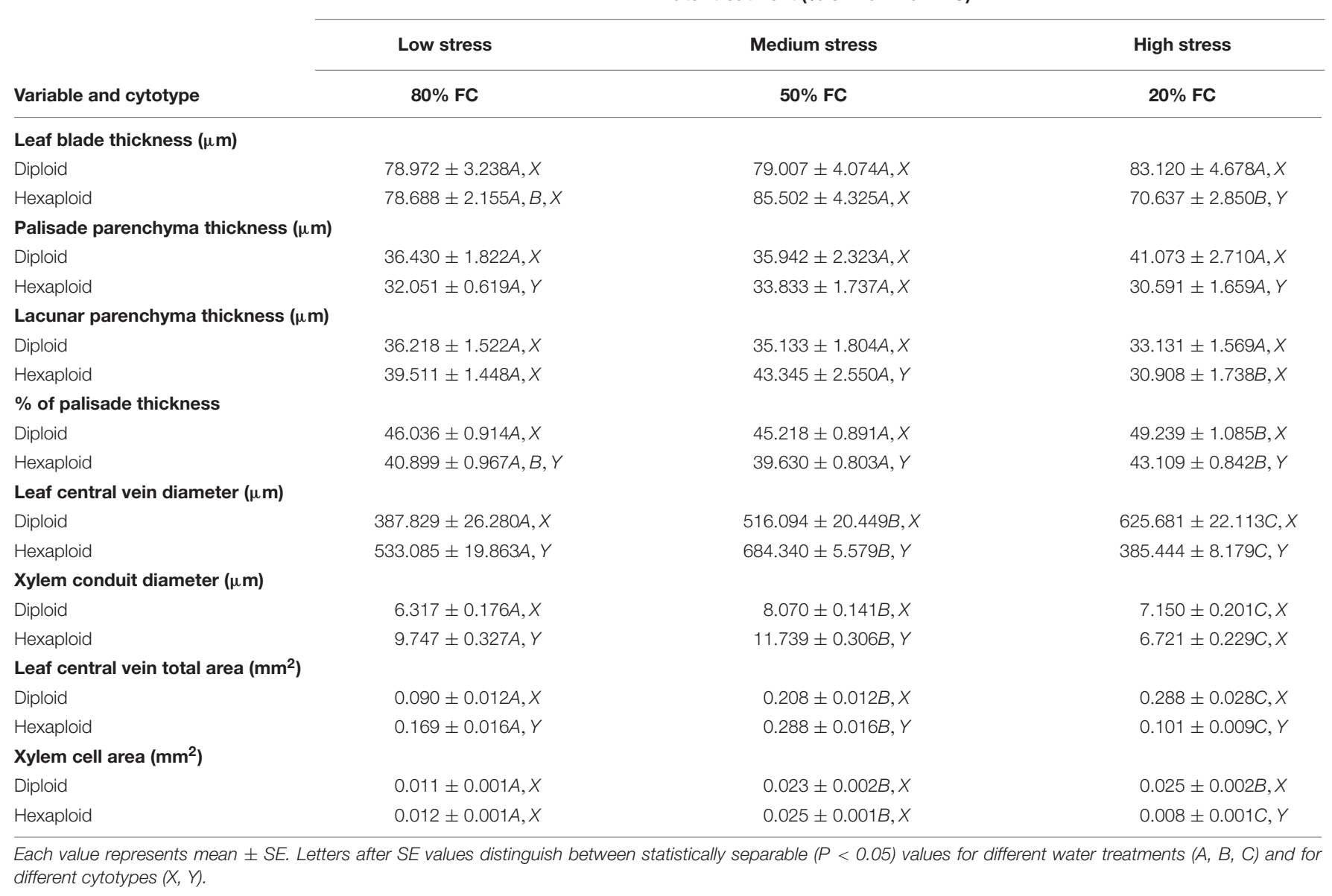




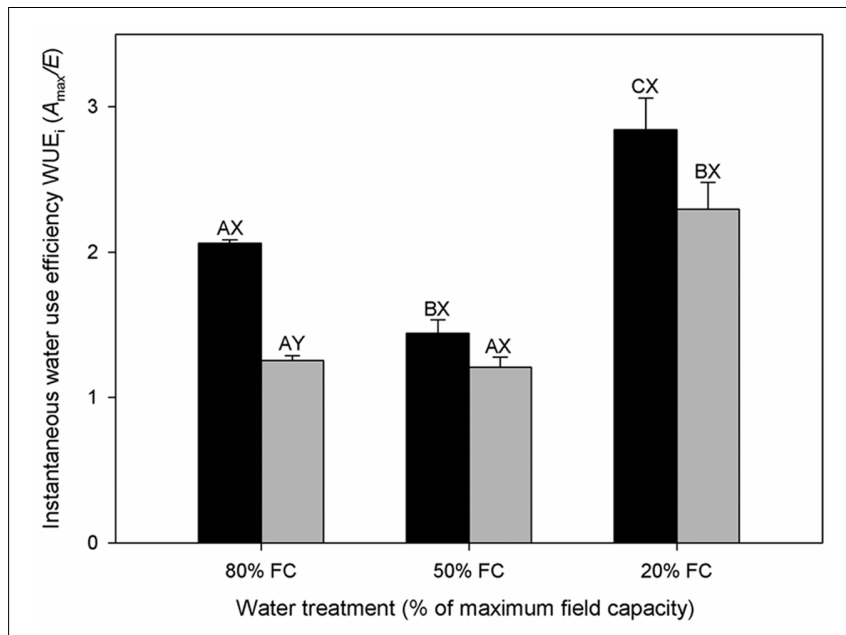

FIGURE 2 | Instantaneous water use efficiency (WUE $E_{i}$ ) of diploids (black bars) and hexaploids (gray bars) under different soil water conditions ( $80 \%$ of maximal FC, $50 \%$ FC, $20 \%$ FC). Each value is presented as mean \pm SE. Letters distinguish between statistically separable $(p<0.05)$ values for different water treatments $(A, B, C)$ and for different cytotypes $(X, Y)$.

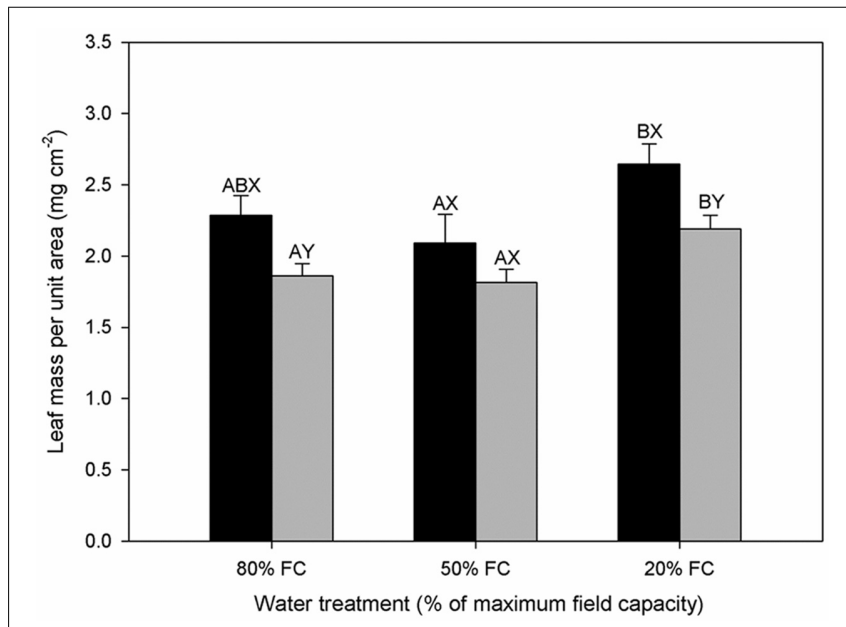

FIGURE 3 | Leaf mass per unit area (LMA) of diploids (black bars) and hexaploids (gray bars) under different soil water conditions $(80 \%$ of maximal FC, $\mathbf{5 0} \% \mathbf{F C , ~} \mathbf{2 0} \% \mathbf{F C )}$. Each value is presented as mean $\pm \mathrm{SE}$. Letters distinguish between statistically separable $(p<0.05)$ values for different water treatments $(A, B, C)$ and for different cytotypes $(X, Y)$.

strategy adapted to growing in environments where drought stress was frequent.

The leaf is a major bottle-neck in the whole plant hydraulic conductivity system (Sack et al., 2003). Anatomical analysis revealed that diploid $C$. angustifolium possessed thicker leaves and palisade tissue (Table 3; Figure 4), and such morphological adjustments may enable the diploid to be more drought resistant than hexaploid (Li et al., 2009). Species that occur in dry areas are able to maintain living tissue at low RWC (Baltzer et al., 2008) and usually have thicker leaves (Rhizopoulou and Psaras, 2003).
Accordingly, LMA tends to increase with leaf density and a high LMA is generally being considered as an adaptation to drought (Niinemets, 2001). Comparisons of LMA and RWC between ploidy levels showed that diploids had significantly higher LMA and lower RWC than hexaploids under extreme drought stress (Table 1; Figure 3), implying that the dense leaf tissues of diploids can withstand a low water content and thus slow water loss from the whole plant (Cunningham et al., 1999; Bucci et al., 2004).

\section{Tradeoff between Hydraulic Efficiency and Safety Associated with Genome Duplication}

For hydraulic transport to be efficient, there should be a compromise between the ability to cope with water stress and the ability to grow at high rates under more favorable water conditions (Piñol and Sala, 2000; Martínez et al., 2002). As an instance, the lower xylem hydraulic conductivity found in higher ploidy levels of Atriplex canescens may be a major constraint counteracting the beneficial effects of their better drought tolerance (Hao et al., 2013). In contrast, the higher hydraulic conductivity of drought-sensitive diploid A. canescens may endow it with a higher growth rate (Stutz and Sanderson, 1983), and thus make it more competitive in environments with relatively high water availability (Sperry and Hacke, 2002). In C. angustifolium, higher hydraulic conductivity was detected in tetraploids than in diploids (Maherali et al., 2009). According to the above mentioned compromise rule, tetraploids may be much more droughtsusceptible but competitive compared with diploids. Surprisingly, vulnerability to water stress induced cavitation was not found to differ across cytotypes (Maherali et al., 2009). The biomass of tetraploids was more negatively impacted by the imposition of water limitation than that of diploids, and both cytotypes had equal competitive abilities when water was limited (Thompson et al., 2015). Our experiments showed that both diploids and hexaploids of $C$. angustifolium were apparently affected by water shortage (as indicated by reductions in biomass accumulation and photosynthetic rate). Nevertheless, we found partial support for the hypothesis that diploids might be better able to cope with drought conditions than the polyploid cytotypes, since they showed physiological (e.g., gas exchange rate) and morphological (e.g., leaf architecture) adjustments appropriate for enduring water loss.

Both water deficit and freeze-thaw cycles can lead to xylem cavitation (Pockman and Sperry, 1996), and thus cytotypes with higher ploidy levels and larger conduits may be more vulnerable to drought stress due to the positive relationship between xylem conduit size and the risk of cavitation (Sperry and Sullivan, 1992; Hacke and Sperry, 2001; Martínez and Pockman, 2002). In C. angustifolium, polyploids generally had wider hydraulic vessel diameters than diploids (Table 3; Figure 5). Consequently, diploids, with their smaller xylem conduits, should be better able to avoid hydraulic disruption formed upon embolism (Pockman and Sperry, 1996), and a greater susceptibility to freezing-induced 

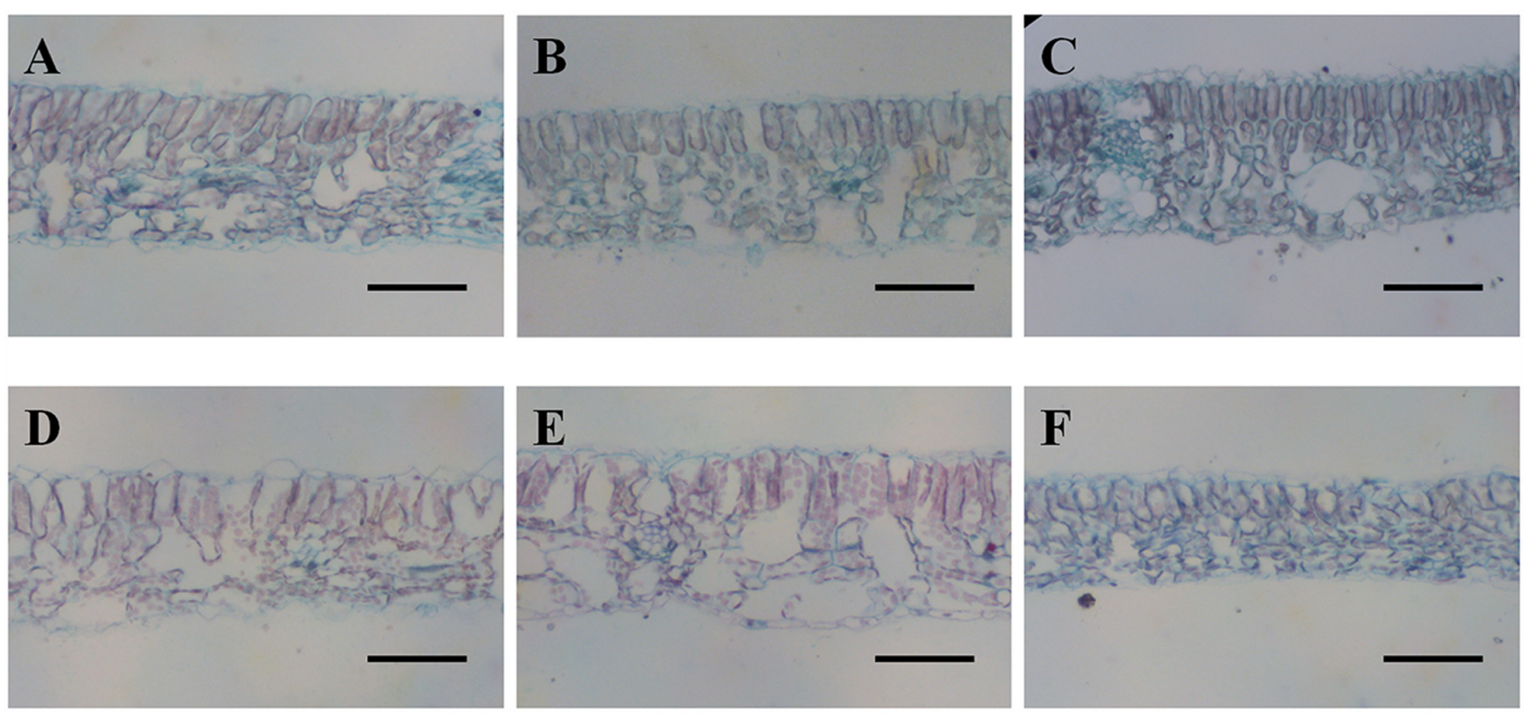

FIGURE 4 | Safranin-Fast Green staining of leaf blade sections from diploids (A, $80 \%$ FC; B, $50 \%$ FC; C, $20 \%$ FC) and hexaploids (D, $80 \%$ FC; E, $50 \%$ FC; F, 20\% FC). Scale bars are $50 \mu \mathrm{m}$.
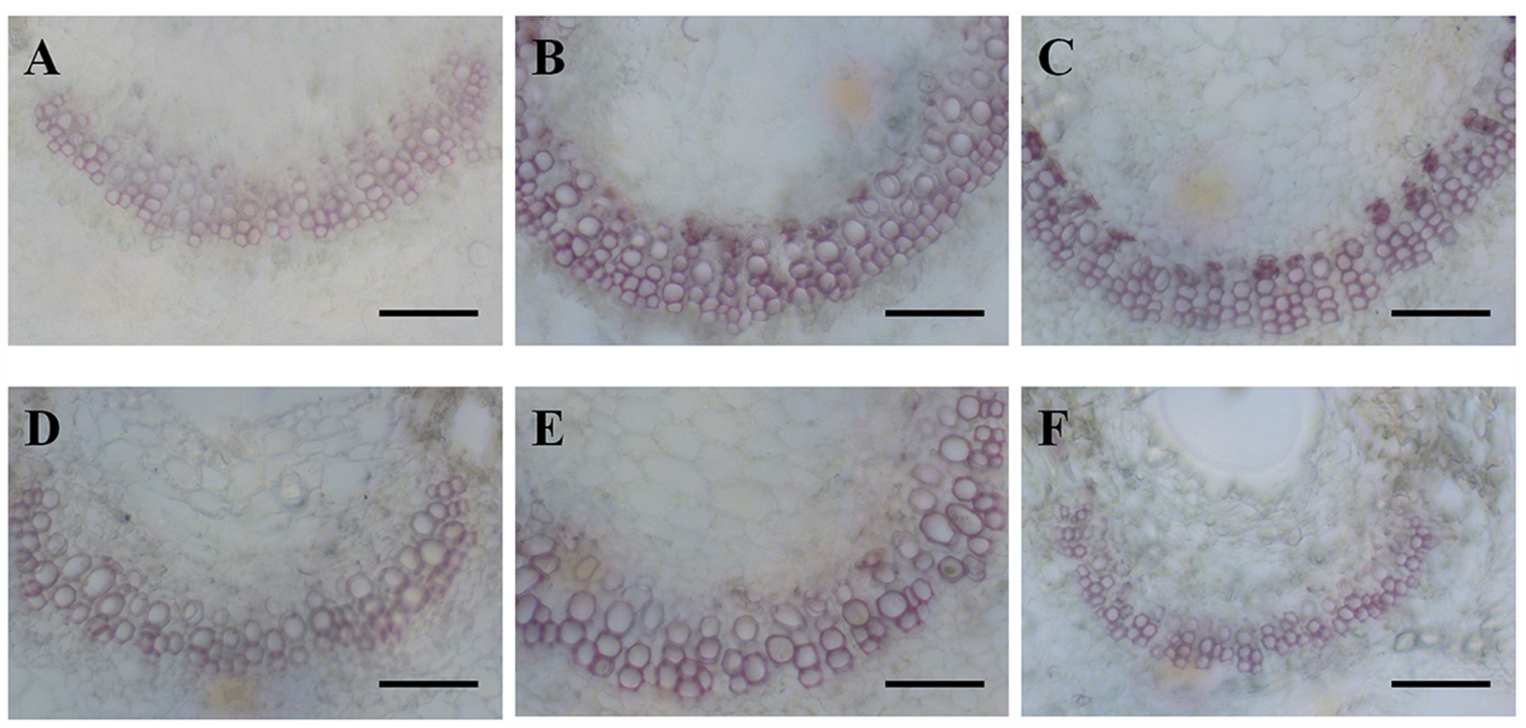

FIGURE 5 | Phloroglucinol-HCl staining of leaf midvein sections from diploids (A, $80 \%$ FC; B, $50 \%$ FC; C, 20\% FC) and hexaploids (D, $80 \%$ FC; $\mathrm{E}, 50 \%$ FC; F, 20\% FC). Scale bars are $50 \mu \mathrm{m}$.

cavitation may exclude polyploids from sites at high altitudes (Maherali et al., 2009). In addition to the smaller xylem conduits, the vessel area of the leaf central vein in diploids was larger than that in hexaploids (Table 3; Figure 5), and the dense vascular bundle found in diploids was consistent with those observed in a few other cases (Maherali et al., 2009; Allario et al., 2011). A high density of major veins such as that found in diploids can provide a large number of parallel xylem pathways for water transport per leaf area, contributing to drought tolerance by routing water around embolized conduits (Scoffoni et al., 2011; Sack et al., 2012).

\section{Adaptive Significance of Polyploidization in Shaping Geographic Distribution}

Two scenarios have been proposed to explain differences in patterns of cytotype distribution (Manzaneda et al., 2012). The adaptive evolutionary scenario suggests that shifts in ploidy level could result in differential stress tolerances (Levin, 2002; Baack, 2004; Kubátová et al., 2008; Sonnleitner et al., 2010; McAllister et al., 2015), which may underlie the ecological divergence and adaptation of cytotypes to novel environments (Ramsey, 2011). In contrast, the environmentally independent explanations ('non-adaptive scenarios') posit that exclusion 
of minority cytotypes (Levin, 1975) and historical processes (Sonnleitner et al., 2010; McAllister et al., 2015) may be the driving force behind the observed distribution patterns. Diploid C. angustifolium inhabits higher altitudes than polyploids, and a similar pattern has also been observed in Senecio carniolicus (Sonnleitner et al., 2010; Huelber et al., 2015) and Centaurea jacea (Hardy et al., 2000). The results of our study illustrate the distinct natures of physiological tolerance in the different ploidy levels, with diploids being less sensitive to drought stress than hexaploids. Thus, the occurrence of diploids in more open habitats at higher altitudes may be the result of adaptation that provides greater resistance to abiotic stress (Körner, 2003; Sonnleitner et al., 2010), whereas the predominance of polyploids in dense and nutrient-rich vegetation at lower altitudes may be due to greater competitiveness compared with the surrounding vegetation (Schönswetter et al., 2007; Ståhlberg, 2009). An earlier study indicated that differences in physiological tolerances in C. angustifolium probably evolved through natural selection acting on plant water relations after polyploidization (Maherali et al., 2009) and thus induced the adaptation of cytotypes to their native habitats (Martin and Husband, 2013). We therefore consider eco-physiological differentiation to be an important adaptive factor underlying the origin of the geographical separation and divergence in climatic niche (Thompson et al., 2014), although other, environmentally independent, factors cannot be excluded.

\section{REFERENCES}

Allario, T., Brumos, J., Colmenero-Flores, J. M., Tadeo, F., Froelicher, Y., Talon, M., et al. (2011). Large changes in anatomy and physiology between diploid Rangpur lime (Citrus limonia) and its autotetraploid are not associated with large changes in leaf gene expression. J. Exp. Bot. 467, 1-13. doi: $10.1093 /$ jxb/erq467

Angert, A. L. (2006). Growth and leaf physiology of monkeyflowers with different altitude ranges. Oecologia 148, 183-194. doi: 10.1007/s00442-006-0361-z

Baack, E. J. (2004). Cytotype segregation on regional and microgeographic scales in snow buttercups (Ranunculus adoneus: Ranunculaceae). Am. J. Bot. 91, 1783-1788. doi: 10.3732/ajb.91.11.1783

Baltzer, J., Davies, S., Bunyavejchewin, S., and Noor, N. (2008). The role of desiccation tolerance in determining tree species distributions along the MalayThai Peninsula. Funct. Ecol. 22, 221-231. doi: 10.3732/ajb.0800414

Brochmann, C., Brysting, A., Alsos, I., Borgen, L., Grundt, H., Scheen, A. C., et al. (2004). Polyploidy in arctic plants. Biol. J. Linn. Soc. 82, 521-536. doi: 10.1111/j.1095-8312.2004.00337.x

Bucci, S., Goldstein, G., Meinzer, F., Scholz, F., Franco, A., and Bustamante, M. (2004). Functional convergence in hydraulic architecture and water relations of tropical savanna trees: from leaf to whole plant. Tree Physiol. 24, 891-899. doi: 10.1093/treephys/24.8.891

Buggs, R. J., and Pannell, J. R. (2007). Ecological differentiation and diploid superiority across a moving ploidy contact zone. Evolution 61, 125-140. doi: 10.1111/j.1558-5646.2007.00010.x

Chaves, M. M., Pereira, J. S., Maroco, J., Rodrigues, M. L., Ricardo, C. P. P., Osório, M. L., et al. (2002). How plants cope with water stress in the field? Photosynthesis and growth. Ann. Bot. 89, 907-916. doi: 10.1093/aob/mcf105

Chen, G., Sun, W. B., and Sun, H. (2007). Ploidy variation in Buddleja L. (Buddlejaceae) in the Sino-Himalayan region and its biogeographical implications. Bot. J. Linn. Soc. 154, 305-312. doi: 10.1111/j.1095-8339.2007.00650.x

Chen, J. R., Hoch, P. C., Raven, P. H., Boufford, D. E., and Wagner, W. L. (2007). Flora of China. Beijing: Science Press.

\section{CONCLUSION}

In conclusion, our results suggest that drought endurance may have an important role in the segregation of $C$. angustifolium cytotypes across altitudinal gradients. Furthermore, genome duplication was suggested to provide the species with an opportunity to adapt to novel environments and thus to colonize new habitats (te Beest et al., 2011). We therefore tentatively suggest that cytotypes inhabiting high altitudes may be more tolerant to drought than those at low altitudes, independent of ploidy levels.

\section{AUTHOR CONTRIBUTIONS}

YWD, YPY, and WG designed the research and wrote the manuscript. WG, JY, XDS, and GJC performed experiments and conducted fieldwork.

\section{ACKNOWLEDGMENT}

This work was supported by National Basic Research Program of China (2014CB954100) and the National Science Foundation of China (31590820, 31590823, and 31270434).

Cornic, G., and Massacci, A. (1996). Leaf photosynthesis under drought stress. in Photosynthesis and the Environment, ed. N. R. Baker (Berlin: Springer).

Cui, X. K., Ao, C. Q., Zhang, Q., Chen, L. T., and Liu, J. Q. (2008). Diploid and tetraploid distribution of Allium przewalskianum Regel. (Liliaceae) in the Qinghai-Tibetan Plateau and adjacent regions. Caryologia 61, 192-200. doi: 10.1080/00087114.2008.10589629

Cunningham, S. A., Summerhayes, B., and Westoby, M. (1999). Evolutionary divergences in leaf structure and chemistry, comparing rainfall and soil nutrient gradients. Ecol. Monogr. 69, 569-588. doi: 10.1890/0012-9615(1999)069[0569:EDILSA]2.0.CO;2

Downton, W., Loveys, B., and Grant, W. (1988). Non-uniform stomatal closure induced by water stress causes putative nonstomatal inhibition of photosynthesis. New Phytol. 110, 503-509. doi: 10.1111/j.1469-8137.1988.tb00289.x

Duchoslav, M., Safarova, L., and Krahulec, F. (2010). Complex distribution patterns, ecology and coexistence of ploidy levels of Allium oleraceum (Alliaceae) in the Czech Republic. Ann. Bot. 105, 719-735. doi: 10.1093/aob/mcq035

Fernandez, R. J., and Reynolds, J. F. (2000). Potential growth and drought tolerance of eight desert grasses: lack of a trade-off? Oecologia 123, 90-98. doi: $10.1007 / \mathrm{s} 004420050993$

Flexas, J., Bota, J., Loreto, F., Cornic, G., and Sharkey, T. (2004). Diffusive and metabolic limitations to photosynthesis under drought and salinity in C3 plants. Plant Biol. 6, 269-279. doi: 10.1055/s-2004-820867

Glennon, K. L., Ritchie, M. E., and Segraves, K. A. (2014). Evidence for shared broad-scale climatic niches of diploid and polyploid plants. Ecol. Lett. 17, 574-582. doi: 10.1111/ele.12259

Godsoe, W., Larson, M. A., Glennon, K. L., and Segraves, K. A. (2013). Polyploidization in Heuchera cylindrica (Saxifragaceae) did not result in a shift in climatic requirements. Am. J. Bot. 100, 496-508. doi: 10.3732/ajb.12 00275

Graciano-Ribeiro, D., and Nassar, N. (2012). A comparative anatomical study in cassava diploid and tetraploid hybrids. Plant Syst. Evol. 298, 1711-1721. doi: 10.1007/s00606-012-0672-y 
Grant, V. (1981). Plant Speciation. New York, NY: Columbia University Press.

Hacke, U. G., and Sperry, J. S. (2001). Functional and ecological xylem anatomy. Perspect. Plant Ecol. Evol. Syst. 4, 97-115. doi: 10.1078/1433-8319-00017

Hammel, H. (1967). Freezing of xylem sap without cavitation. Plant Physiol. 42, 55-66. doi: 10.1104/pp.42.1.55

Hao, G. Y., Lucero, M. E., Sanderson, S. C., Zacharias, E. H., and Holbrook, N. M. (2013). Polyploidy enhances the occupation of heterogeneous environments through hydraulic related trade-offs in Atriplex canescens (Chenopodiaceae). New Phytol. 197, 970-978. doi: 10.1111/nph.12051

Hardy, O. J., Vanderhoeven, S., De Loose, M., and Meerts, P. (2000). Ecological, morphological and allozymic differentiation between diploid and tetraploid knapweeds (Centaurea jacea) from a contact zone in the Belgian Ardennes. New Phytol. 146, 281-290. doi: 10.1046/j.1469-8137.2000.00631.x

Hasibeder, R., Fuchslueger, L., Richter, A., and Bahn, M. (2015). Summer drought alters carbon allocation to roots and root respiration in mountain grassland. New Phytol. 205, 1117-1127. doi: 10.1111/nph.13146

Huelber, K., Sonnleitner, M., Suda, J., Krejcikova, J., Schoenswetter, P., Schneeweiss, G. M., et al. (2015). Ecological differentiation, lack of hybrids involving diploids, and asymmetric gene flow between polyploids in narrow contact zones of Senecio carniolicus (syn. Jacobaea carniolica, Asteraceae). Ecol. Evol. 5, 1224-1234. doi: 10.1002/ece3.1430

Husband, B. C., and Schemske, D. W. (1998). Cytotype distribution at a diploidtetraploid contact zone in Chamerion (Epilobium) angustifolium (Onagraceae). Am. J. Bot. 85, 1688-1694. doi: 10.2307/2446502

Körner, C. (2003). Alpine Plant Life: Functional Plant Ecology of High Mountain Ecosystems. Berlin: Springer.

Kubátová, B., Trávníček, P., Bastlová, D., Čurn, V., Jarolímová, V., and Suda, J. (2008). DNA ploidy-level variation in native and invasive populations of Lythrum salicaria at a large geographical scale. J. Biogeogr. 35, 167-176. doi: 10.1111/j.1365-2699.2007.01781.x

Lauteri, M., Scartazza, A., Guido, M., and Brugnoli, E. (1997). Genetic variation in photosynthetic capacity, carbon isotope discrimination and mesophyll conductance in provenances of Castanea sativa adapted to different environments. Funct. Ecol. 11, 675-683. doi: 10.1046/j.1365-2435.1997. 00140.x

Leitch, I. J., and Bennett, M. D. (1997). Polyploidy in angiosperms. Trends Plant Sci. 2, 470-476. doi: 10.1016/S1360-1385(97)01154-0

Levin, D. A. (1975). Minority cytotype exclusion in local plant populations. Taxon 24, 35-43. doi: 10.1007/s00442-008-1156-1

Levin, D. A. (1983). Polyploidy and novelty in flowering plants. Am. Nat. 122, 1-25. doi: $10.1086 / 284115$

Levin, D. A. (2002). The Role of Chromosomal Change in Plant Evolution. New York, NY: Oxford University Press.

Levin, D. A. (2004). The ecological transition in speciation. New Phytol. 161, 91-96. doi: 10.1046/j.1469-8137.2003.00921.x

Li, D. W., Liu, Y. F., Zhong, C. H., and Huang, H. W. (2010). Morphological and cytotype variation of wild kiwifruit (Actinidia chinensis complex) along an altitudinal and longitudinal gradient in central-west China. Bot. J. Linn. Soc. 164, 72-83. doi: 10.1111/j.1095-8339.2010.01073.x

Li, W. D., Biswas, D. K., Xu, H., Xu, C. Q., Wang, X. Z., Liu, J. K., et al. (2009). Photosynthetic responses to chromosome doubling in relation to leaf anatomy in Lonicera japonica subjected to water stress. Funct. Plant Biol. 36, 783-792. doi: 10.1071/FP09022

Li, X. W., and Li, J. (1993). A preliminary floristic study on the seed plants from the region of Hengduan Mountain. Acta Bot. Yunnan. 15, 217-231.

Liang, Q. L., Hu, X. X., Wu, G. L., and Liu, J. Q. (2015). Cryptic and repeated "allopolyploid" speciation within Allium przewalskianum Regel. (Alliaceae) from the Qinghai-Tibet Plateau. Org. Divers. Evol. 15, 265-276. doi: 10.1007/s13127-014-0196-0

Liu, J. Q. (2004). Uniformity of karyotypes in Ligularia (Asteraceae: Senecioneae), a highly diversified genus of the eastern Qinghai-Tibet Plateau highlands and adjacent areas. Bot. J. Linn. Soc. 144, 329-342. doi: 10.1111/j.10958339.2003.00225.x

Liu, R. R., Wang, A. L., Tian, X. M., Wang, D. S., and Liu, J. Q. (2010). Uniformity of karyotypes in Rheum (Polygonaceae), a species-rich genus in the Qinghai-Tibetan Plateau and adjacent regions. Caryologia 63, 82-90. doi: $10.1080 / 00087114.2010 .10589711$
Liu, Y. A., Feng, H. S., Chen, Z. G., Chang, X. Y., Liu, R. J., Dou, Q. W., et al. (2006). Common methods of karyotype analysis in plant. Guizhou Agric. Sci. 1, 98-102. doi: 10.1016/S1671-2927(06)60025-4

Ma, F., Xu, T. T., Ji, M. F., and Zhao, C. M. (2014). Differential drought tolerance in tree populations from contrasting elevations. AoB Plants 6: plu069. doi: 10.1093/aobpla/plu069

Ma, F., Zhao, C. M., Milne, R., Ji, M. F., Chen, L. T., and Liu, J. Q. (2010). Enhanced drought-tolerance in the homoploid hybrid species Pinus densata: implication for its habitat divergence from two progenitors. New Phytol. 185, 204-216. doi: 10.1111/j.1469-8137.2009.03037.x

Maherali, H., Walden, A. E., and Husband, B. C. (2009). Genome duplication and the evolution of physiological responses to water stress. New Phytol. 184, 721-731. doi: 10.1111/j.1469-8137.2009.02997.x

Manzaneda, A. J., Rey, P. J., Bastida, J. M., Weiss-Lehman, C., Raskin, E., and Mitchell-Olds, T. (2012). Environmental aridity is associated with cytotype segregation and polyploidy occurrence in Brachypodium distachyon (Poaceae). New Phytol. 193, 797-805. doi: 10.1111/j.1469-8137.2011. 03988.x

Maroco, J. P., Rodrigues, M. L., Lopes, C., and Chaves, M. M. (2002). Limitations to leaf photosynthesis in field-grown grapevine under drought-metabolic and modelling approaches. Funct. Plant Biol. 29, 451-459. doi: 10.1071/PP 01040

Martin, S. L., and Husband, B. C. (2013). Adaptation of diploid and tetraploid Chamerion angustifolium to elevation but not local environment. Evolution 67, 1780-1791. doi: 10.1111/evo.12065

Martínez, V. J., and Pockman, W. T. (2002). The vulnerability to freezing-induced xylem cavitation of Larrea tridentata (Zygophyllaceae) in the Chihuahuan desert. Am. J. Bot. 89, 1916-1924. doi: 10.3732/ajb.89.12.1916

Martínez, V. J., Prat, E., Oliveras, I., and Piñol, J. (2002). Xylem hydraulic properties of roots and stems of nine Mediterranean woody species. Oecologia 133, 19-29. doi: 10.1007/s00442-002-1009-2

Maxwell, K., and Johnson, G. N. (2000). Chlorophyll fluorescence-a practical guide. J. Exp. Bot. 51, 659-668. doi: 10.1093/jexbot/51.345.659

McAllister, C., Blaine, R., Kron, P., Bennett, B., Garrett, H., Kidson, J., et al. (2015). Environmental correlates of cytotype distribution in Andropogon gerardii (Poaceae). Am. J. Bot. 102, 92-102. doi: 10.3732/ajb.1400296

McIntyre, P. J. (2012). Polyploidy associated with altered and broader ecological niches in the Claytonia perfoliata (Portulacaceae) species complex. Am. J. Bot. 99, 655-662. doi: 10.3732/ajb.1100466

Mena-Petite, A., Gonzalez Moro, B., Gonzalez Murua, C., Lacuesta, M., and Rueda, A. M. (2000). Sequential effects of acidic precipitation and drought on photosynthesis and chlorophyll fluorescence parameters of Pinus radiata D. Don seedlings. J. Plant Physiol. 156, 84-92. doi: 10.1016/S0176-1617(00) 80276-X

Meng, Y., Yang, Y. P., Sun, H., Deng, T., and Nie, Z. L. (2014). Chromosome numbers, karyotypes, and polyploidy evolution of Anaphalis species (Asteraceae: Gnaphalieae) from the Hengduan Mountains, SW China. Caryologia 67, 238-249. doi: 10.1080/0144235X.2014.974352

Mosquin, T. (1967). Evidence for autopolyploidy in Epilobium angustifolium (Onagraceae). Evolution 21, 713-719. doi: 10.2307/2406768

Muller, B., Pantin, F., Génard, M., Turc, O., Freixes, S., Piques, M., et al. (2011). Water deficits uncouple growth from photosynthesis, increase $\mathrm{C}$ content, and modify the relationships between C and growth in sink organs. J. Exp. Bot. 62, 1715-1729. doi: 10.1093/jxb/erq438

Nie, Z. L., Wen, J., Gu, Z. J., Boufford, D. E., and Sun, H. (2005). Polyploidy in the flora of the Hengduan Mountains hotspot, southwestern China. Ann. Mo. Bot. Gard. 92, 275-306.

Niinemets, Ü. (2001). Global-scale climatic controls of leaf dry mass per area, density, and thickness in trees and shrubs. Ecology 82, 453-469. doi: 10.1890/0012-9658(2001)082[0453:GSCCOL]2.0.CO;2

Otieno, D., Schmidt, M., Adiku, S., and Tenhunen, J. (2005). Physiological and morphological responses to water stress in two Acacia species from contrasting habitats. Tree Physiol. 25, 361-371. doi: 10.1093/treephys/25. 3.361

Piñol, J., and Sala, A. (2000). Ecological implications of xylem cavitation for several Pinaceae in the Pacific Northern USA. Funct. Ecol. 14, 538-545. doi: 10.1046/j.1365-2435.2000.t01-1-00451.x 
Pockman, W. T., and Sperry, J. S. (1996). Freezing-induced xylem cavitation and the northern limit of Larrea tridentata. Oecologia 109, 19-27. doi: $10.1007 / \mathrm{s} 004420050053$

Ramsey, J. (2011). Polyploidy and ecological adaptation in wild yarrow. Proc. Natl. Acad. Sci. U.S.A. 108, 7096-7101. doi: 10.1073/pnas.1016631108

Ramsey, J., and Schemske, D. W. (2002). Neopolyploidy in flowering plants. Annu. Rev. Ecol. Syst. 33, 589-639. doi: 10.1146/annurev.ecolsys.33.010802. 150437

Rhizopoulou, S., and Psaras, G. K. (2003). Development and structure of Droughttolerant leaves of the Mediterranean Shrub Capparis spinosa L. Ann. Bot. 92, 377-383. doi: $10.1093 / \mathrm{aob} / \mathrm{mcg} 149$

Ricca, M., Beecher, F., Boles, S., Temsch, E., Greilhuber, J., Karlin, E., et al. (2008). Cytotype variation and allopolyploidy in North American species of the Sphagnum subsecundum complex (Sphagnaceae). Am. J. Bot. 95, 1606-1620. doi: $10.3732 / a j b .0800148$

Sack, L., Cowan, P., Jaikumar, N., and Holbrook, N. (2003). The 'hydrology'of leaves: co-ordination of structure and function in temperate woody species. Plant Cell Environ. 26, 1343-1356. doi: 10.1046/j.0016-8025.2003. 01058.x

Sack, L., Scoffoni, C., McKown, A. D., Frole, K., Rawls, M., Havran, J. C., et al. (2012). Developmentally based scaling of leaf venation architecture explains global ecological patterns. Nat. Commun. 3:837. doi: 10.1038/ncomms1835

Sapeta, H., Miguel Costa, J., Lourenco, T., Maroco, J., van der Linde, P., and Margarida Oliveira, M. (2013). Drought stress response in Jatropha curcas: Growth and physiology. Environ. Exp. Bot. 85, 76-84. doi: 10.1016/j.envexpbot.2012.08.012

Schönswetter, P., Lachmayer, M., Lettner, C., Prehsler, D., Rechnitzer, S., Reich, D. S., et al. (2007). Sympatric diploid and hexaploid cytotypes of Senecio carniolicus (Asteraceae) in the Eastern Alps are separated along an altitudinal gradient. J. Plant Res. 120, 721-725. doi: 10.1007/s10265-007-0 $108-\mathrm{x}$

Scoffoni, C., Rawls, M., McKown, A., Cochard, H., and Sack, L. (2011). Decline of leaf hydraulic conductance with dehydration: relationship to leaf size and venation architecture. Plant Physiol. 156, 832-843. doi: 10.1104/pp.111. 173856

Sobrado, M., and Turner, N. C. (1986). Photosynthesis, dry matter accumulation and distribution in the wild sunflower Helianthus petiolaris and the cultivated sunflower Helianthus annuus as influenced by water deficits. Oecologia 69 , 181-187. doi: 10.1007/BF00377619

Soltis, D. E., Bell, C. D., Paterson, A. H., Zheng, C., Sankoff, D., Depamphilis, C. W., et al. (2009). Polyploidy and angiosperm diversification. Am. J. Bot. 96, 336-348. doi: $10.3732 / a j b .0800079$

Soltis, P. S., Liu, X., Marchant, D. B., Visger, C. J., and Soltis, D. E. (2014). Polyploidy and novelty: Gottlieb's legacy. Philos. Trans. R. Soc. B Biol. Sci. 369:20130351. doi: 10.1098/rstb.2013.0351

Sonnleitner, M., Flatscher, R., García, P. E., Rauchová, J., Suda, J., Schneeweiss, G. M., et al. (2010). Distribution and habitat segregation on different spatial scales among diploid, tetraploid and hexaploid cytotypes of Senecio carniolicus (Asteraceae) in the Eastern Alps. Ann. Bot. 106, 967-977. doi: 10.1093/aob/mcq192

Sperry, J., and Hacke, U. (2002). Desert shrub water relations with respect to soil characteristics and plant functional type. Funct. Ecol. 16, 367-378. doi: 10.1046/j.1365-2435.2002.00628.x

Sperry, J. S., and Sullivan, J. E. (1992). Xylem embolism in response to freeze-thaw cycles and water stress in ring-porous, diffuse-porous, and conifer species. Plant Physiol. 100, 605-613. doi: 10.1104/pp.100.2.605

Ståhlberg, D. (2009). Habitat differentiation, hybridization and gene flow patterns in mixed populations of diploid and autotetraploid Dactylorhiza maculata s.l. (Orchidaceae). Evol. Ecol. 23, 295-328. doi: 10.1007/s10682-0079228-y

Stutz, H. C., and Sanderson, S. C. (1983). Evolutionary studies of Atriplex: chromosome races of A. confertifolia (shadscale). Am. J. Bot. 70, 1536-1547. doi: $10.2307 / 2443352$

Sun, X. D., Feng, Z. H., Meng, L. S., Zhu, J., and Anja, G. (2013). Arabidopsis ASL11/LBD15 is involved in shoot apical meristem development and regulates WUS expression. Planta 237, 1367-1378. doi: 10.1007/s00425-013-1 $844-x$ te Beest, M., Le Roux, J. J., Richardson, D. M., Brysting, A. K., Suda, J., Kubešová, M., et al. (2011). The more the better? The role of polyploidy in facilitating plant invasions. Ann. Bot. 109, 19-45. doi: 10.1093/aob/mcr277

Tezara, W., Mitchell, V., Driscoll, S., and Lawlor, D. (1999). Water stress inhibits plant photosynthesis by decreasing coupling factor and ATP. Nature 401, 914-917. doi: 10.1038/44842

Theodoridis, S., Randin, C., Broennimann, O., Patsiou, T., and Conti, E. (2013). Divergent and narrower climatic niches characterize polyploid species of European primroses in Primula sect. Aleuritia. J. Biogeogr. 40, 1278-1289. doi: 10.1111/jbi.12085

Thompson, K. A., Husband, B. C., and Maherali, H. (2014). Climatic niche differences between diploid and tetraploid cytotypes of Chamerion angustifolium (Onagraceae). Am. J. Bot. 101, 1868-1875. doi: 10.3732/ajb.1400184

Thompson, K. A., Husband, B. C., and Maherali, H. (2015). No influence of water limitation on the outcome of competition between diploid and tetraploid Chamerion angustifolium (Onagraceae). J. Ecol. 103, 733-741. doi: $10.1111 / 1365-2745.12384$

Tian, X. M., Zhou, X. Y., and Gong, N. (2011). Applications of flow cytometryin plant research-analysis of nuclear DNA content and ploidy levelin plant cells. Chin. Agric. Sci. Bull. 27, 21-27.

Visser, V., and Molofsky, J. (2015). Ecological niche differentiation of polyploidization is not supported by environmental differences among species in a cosmopolitan grass genus. Am. J. Bot. 102, 36-49. doi: 10.3732/ajb.140 0432

Wheeler, J. K., Sperry, J. S., Hacke, U. G., and Hoang, N. (2005). Inter-vessel pitting and cavitation in woody Rosaceae and other vesselled plants: a basis for a safety versus efficiency trade-off in xylem transport. Plant Cell Environ. 28, 800-812. doi: 10.1111/j.1365-3040.2005.01330.x

Wu, H., Ma, Z., Wang, M. M., Qin, A. L., Ran, J. H., and Wang, X. Q. (2016). A high frequency of allopolyploid speciation in the gymnospermous genus Ephedra and its possible association with some biological and ecological features. Mol. Ecol. 25, 1192-1210. doi: 10.1111/mec.13538

Wu, Z. Y. (1988). Hengduan mountain flora and her significance. J. Jpn. Bot. 63, 297-311.

Wu, Z. Y., and Wu, S. G. (1998). "A proposal for a new floristic kingdom (realm): the E. Asiatic Kingdom, its delineation and characteristics," in Proceedings of the First International Symposium of Floristic Characteristics and Diversity of East Asian Plants, (Beijing: China Higher Education Press).

Xie, H. Y., Ash, J. E., Linde, C. C., Cunningham, S., and Nicotra, A. (2014). Himalayan-Tibetan plateau uplift drives divergence of polyploid poppies: Meconopsis viguier (Papaveraceae). PLoS ONE 9:e99177. doi: 10.1371/journal.pone.0099177

Yamasaki, S., and Dillenburg, L. R. (1999). Measurements of leaf relative water content in Araucaria angustifolia. Revista Brasilleira Fisiologia Vegetal 11, 69-75.

Yang, F., and Miao, L. F. (2010). Adaptive responses to progressive Drought stress in two poplar species originating from different altitudes. Silva Fennica 44, 23-37. doi: 10.1111/j.1399-3054.2010.01375.x

Yang, J., Hu, L. J., Wang, Z. K., Zhu, W. L., and Meng, L. H. (2014). Responses to drought stress among sex morphs of Oxyria sinensis (Polygonaceae), a subdioecious perennial herb native to the East Himalayas. Ecol. Evol. 4, 40334040. doi: $10.1002 /$ ece3.1178

Yu, F., Kress, W. J., and Gao, J. Y. (2010). Morphology, distribution, and chromosome counts of two varieties of Hedychium villosum (Zingiberaceae). J. Syst. Evol. 48, 344-349. doi: 10.1111/j.1759-6831.2010.00094.x

Yuan, Q., and Yang, Q. E. (2006). Polyploidy in Aconitum subgenus Lycoctonum (Ranunculaceae). Bot. J. Linn. Soc. 150, 343-353. doi: 10.1111/j.10958339.2006.00468.x

Yuan, Q., and Yang, Q. E. (2008). Low incidence of polyploids and high uniformity of karyotypes displayed by Delphinium (Ranunculaceae) in the Hengduan Mountains region of south-west China. Bot. J. Linn. Soc. 158, 172-188. doi: 10.1111/j.1095-8339.2008.00849.x

Zhai, Y. H., Yang, Y., Xing, Y. W., Ji, Y. H., and Zhou, Z. K. (2011). Diploid and tetraploid distribution of Allium wallichii kunth (Ailiaceae) in the Yunnan-Guizhou Plateau. Plant Sci. J. 29, 50-57. doi: 10.3724/SP.J.1142.2011. 10050 
Zhang, J. W., and Marshall, J. D. (1994). Population differences in water-use efficiency of well-watered and water-stressed western larch seedlings. Can. J. For. Res. 24, 92-99. doi: 10.1139/x94-014

Zhou, J., Lee, C., Zhong, R., and Ye, Z. H. (2009). MYB58 and MYB63 are transcriptional activators of the lignin biosynthetic pathway during secondary cell wall formation in Arabidopsis. Plant Cell 21, 248-266. doi: 10.1105/tpc.108.063321

Zhu, X. B., Cox, R. M., and Arp, P. A. (2000). Effects of xylem cavitation and freezing injury on dieback of yellow birch (Betula alleghaniensis) in relation to a simulated winter thaw. Tree Physiol. 20, 541-547. doi: $10.1093 /$ treephys/20.8.541
Conflict of Interest Statement: The authors declare that the research was conducted in the absence of any commercial or financial relationships that could be construed as a potential conflict of interest.

Copyright (c) 2016 Guo, Yang, Sun, Chen, Yang and Duan. This is an open-access article distributed under the terms of the Creative Commons Attribution License (CC BY). The use, distribution or reproduction in other forums is permitted, provided the original author(s) or licensor are credited and that the original publication in this journal is cited, in accordance with accepted academic practice. No use, distribution or reproduction is permitted which does not comply with these terms. 